Journal of Balkumari College

ISSN : 2467-9321 Website: http://www.nepjol.info/index.php/jbkc

Volume : 9, Issue : 1, June 2020, Page No.: 101-104

\title{
Impact of Merger on Financial Performance of Nepalese Commercial Bank
}

\author{
Krishna Prasad Acharya* \\ Lecturer, Faculty of Management \\ Balkumari College, Nepal
}

\begin{abstract}
Mergers and Acquisitions have become the most widely used business strategy of restructuring and strong financial institution to achieve competitiveness, to ensure long term existence with suitable profitability, to forge entering in new markets, and to ascertain the capital base etc. Specially, the merger law policy-2068 and monetary policy 2072 issued by Nepal Rastra Bank, the regulatory body of banks in Nepal, have been experienced as the most effective weapons for merger and acquisition in Nepalese Banking industry. This study makes an attempt to the latest Monetary Policy lays down measures meant to encourage banks to merge. By Shrawan 2076, commercial banks are required to maintain an average interest rate spread (the difference between rates on loans and deposits) of 4.4 percent from the current 4.5 percent; banks that complete mergers and acquisitions by that time will get a one-year extension. Also, by Shrawan 2076, commercial banks are required to float at least 25 percent of their paid-up capital in debentures; banks that decide to tie the knot by that deadline will get a one-year reprieve. A merged bank also does not have to seek Nepal Rastra Bank's approval to open new branches. Currently, the board of directors, CEOs and deputy CEOs are required to abide by a cooling-off period of six months during which they cannot join another bank. This restriction will not apply to executives of a merged bank. The argument for mergers and acquisitions go something like this. There are just too many banks and financial institutions in Nepal. As of Ashad 2076, there were 28 commercial banks (Class A), 32 development banks (Class B), 24 finance companies (Class C) and 91 micro-credit companies (Class D). Conceivably, larger banks should be able to fund large infrastructure projects individually. The existence of larger Nepali banks could also make it easier for them to branch into India. Bigger Nepali banks will be able to compete with foreign banks better on Nepali soil.
\end{abstract}

Key Words: Big merger, Financial Performance, Banks, Nepal .

\section{INTRODUCTION}

The Nepali financial system, particularly the banking sector, has seen several policy changes in a short period of time. Nepal Rastra Bank (NRB) has a history of dumping long-term policies in the middle of its course. There was a time when the Rastra bank would issue as many permission as there were applications for new banking and financial institutions (BFIs) in Nepal - specifically, from 2064 to 2069. There was a saying that banking was a post-retirement business of senior executives of the NRB. As many as 67 licenses were issued to new BFIs in five years from 2065/2069. However, NRB abruptly put a squeeze on new licenses at the mid of 2069, when there were 211 BFIs in Nepal, and started popularizing the term merger and acquisitions (M\&A).

This shows nothing but lack of anticipation among the policymakers. The rampant controls on the market - frequent short-term policies to control the interest rates, cash reserve ratio, spread rates and credit flow - in a free-market economy is nothing but hindsight of poorly defined policies. For example, NRB all of a sudden raised the paid-up capital of BFIs through the monetary policy of 2072/2073 four-fold without reckoning its probable impact on the stock market. The argument is not whether the policy was wrong, no it wasn't. But the policy-makers failed to restrain the BFIs from issuing right shares and bonus shares to accumulate the required paid-up capital.

So rather than getting into big mergers and acquisitions, the stock market was awash with the shares of BFIs. The result is what the Nepal stock exchange is facing now: stocks that were worth Rs 3000 then are now trading for less than Rs 600. Therefore, unless we have a culture of making decisions on a policy only after doing research on both the positive and negative aspects, it will not bode well for both the industry and the nation.

* Corresponding author: krishp_bi@yahoo.com 
Since NRB is all set to unveil the monetary policy for 2075/76 and its Governor Chiranjibi Nepal has suggested BFIs start finding the right and acceptable partner for a big merger, let's analyze the good and the ugly sides of it.

The Nepali financial market has been awash with merger talks since the incumbent governor took office. Some economists and policy-makers argue that there should be no more than 15 commercial banks in Nepal currently there are 28 . However, such arguments are not backed by any substantial research. To better understand the advantages of mergers, the pervasive banking problems should be understood first.

One major issue of the Nepali financial market is the large number of urban-based BFIs with lower paid-up capital. There were 151 BFIs in 2075. Given the size of the economy, this number is unnecessarily high. Unhealthy competition in deposit collection and loan disbursement, lack of capacity to finance large-scale projects, higher interest rate sensitivity and increment in flow of bad loans are some of the problems that an economy faces when it has a large number of small BFIs in the market.

Similarly, interest rate sensitivity is another problem that banks face with lower capital base. The performance of small banks is highly elastic to interest rate change. Thus, a small change in the interest rate costs these banks heavily, and hence they cannot reduce their interest rate even if they want to. And when concerned bodies try to do so, the result is significant reduction in the profitability, and the impact is seen in the stock market and economy as a whole.

\section{LITERATURE REVIEW}

Harrison et al. (1991) analyse the post-acquisition performance of 1100 US firms in the period of 19701989 and demonstrates that the acquisition remains beneficial for the acquiring firms \& resulted in improvement of profitability ratios. Lees (1992) finds that the merger remains beneficial for the acquiring firm and in the postmerger period the profitability has increased with higher rate as compared to the pre-merger period. Shanmugam and Nair (2004) analysed the impact of merger on financial performance of 54 Malaysian banks. By applying the paired t-test on 1990-2000 data, it is found that merger has strengthened the financial position of banks and resulted in improvement in profitability ratios. Feroz et al. (2005) finds that financial performance enhanced significantly after merger. The financial ratios are in improved version after merger. Rani et al. (2015) analyses the pre- and post-merger financial performance of 305 Indian firms using a paired t-test. The study finds that after the merger the financial performance has upgraded and Return on equity, Return on capital employed, the Net profit margin increased significantly. Daniya et al. (2016) examine the pre- and post merger financial performance of 24 Nigerian banks and concludes that the after the merger the financial performance improved and, as a result, the profitability ratios increased significantly. Das (2014) studied the pre- and post-merger financial performance of regional rural banks using a paired t-test. The study finds that the merger has a positive impact on financial performance and increases profitability significantly. Patel and Shah (2016) investigate the pre- and post merger financial performance of the Indian banking industry covering a period of 2001 to 2014. They find the impact of merger to be positive and significant for financial performance.

\section{OBJECTIVES OF THE STUDY}

1. To identify the impact of big merger on EPS and market value per share.

2. To critically analyze the impact of mergers and acquisitions on the operating performance of the firm in Nepal

3. To strategically evaluate the impact on shareholders' wealth post-M\&A.

\section{LIMITATIONS OF THE STUDY}

The research deals with a specific period on the before and after merger of commercial bank and that is the key limitation of the study. Hence, the implications of this study cannot be applied as every financial institution has its own conceptualization with regard to the effects of mergers and acquisitions. The country-specific nature is the other limitation, since these organizations work within individual financial environments pertinent to these countries. 


\section{RESEARCH METHOD}

This research is descriptive analysis. It is based only on secondary data; it was collected from a wide array of research papers, capital market, Journals, Magazines, Books, Websites and company's database etc. The data were collected from the latest merged companies, and studied about its annual reports. Some Journal and Paper were studied to help the additional knowledge about the subject matter and helped to ascertain the problem of the study.

\section{ANALYSIS OF DATA}

Analyzing the collected data, the difference between various indices of the company before and after merger is seen. The data is based on the third quarter report of fiscal year 2075/76 and 2076/77 respectively before and after merger. The different data is presented in the tables below.

Table 1: Share Capital (Amount In Arab)

\begin{tabular}{|l|c|c|c|}
\hline \multicolumn{1}{|c|}{ Company Name } & Before Merger & After Merger & Increase/Decrease \\
\hline Global IME bank & 10.31 & 18.97 & 8.66 \\
\hline NMB Bank & 9.62 & 13.95 & 4.33 \\
\hline Prime Com. Bank & 8.03 & 13.98 & 5.95 \\
\hline
\end{tabular}

Sources: 3rd Quarter report 2075/76 and 2076/77

Table 2 : Earning per Share In Rs

\begin{tabular}{|l|c|c|c|}
\hline \multicolumn{1}{|c|}{ Company Name } & Before Merger & After Merger & Increase/Decrease \\
\hline Global IME bank & 24.21 & 22.53 & -1.68 \\
\hline NMB Bank & 22.99 & 19.58 & -.3 .41 \\
\hline Prime Com. Bank & 25.69 & 19.36 & -6.33 \\
\hline
\end{tabular}

Sources: 3rd Quarter report 2075/76 and 2076/77

Table 3 : P.E. Ratio In percentage

\begin{tabular}{|l|c|c|c|}
\hline \multicolumn{1}{|c|}{ Company Name } & Before Merger & After Merger & Increase/Decrease \\
\hline Global IME bank & 11.19 & 13.10 & 1.91 \\
\hline NMB Bank & 15.55 & 20.17 & 4.62 \\
\hline Prime Com. Bank & 12.84 & 13.02 & 0.18 \\
\hline
\end{tabular}

Sources : $3^{\text {rd }}$ Quarter report 2075/76 and 2076/77

Table 4 : Net worth per share in Rs

\begin{tabular}{|l|c|c|c|}
\hline \multicolumn{1}{|c|}{ Company Name } & Before Merger & After Merger & Increase/Decrease \\
\hline Global IME bank & 149.72 & 145.23 & -4.49 \\
\hline NMB Bank & 176.01 & 148.78 & -27.23 \\
\hline Prime Com. Bank & 158.48 & 144.62 & -13.86 \\
\hline
\end{tabular}

Sources: $3^{\text {rd }}$ Quarter report 2075/76 and 2076/77

Table 5 : Market value per share in Rs

\begin{tabular}{|l|c|c|c|}
\hline \multicolumn{1}{|c|}{ Company Name } & Before Merger & After Merger & Increase/Decrease \\
\hline Global IME bank & 271 & 248 & -23 \\
\hline NMB Bank & 356 & 377 & 21 \\
\hline Prime Com. Bank & 330 & 252 & -78 \\
\hline
\end{tabular}

Sources: www.sharesansar.com 


\section{MAJOR FINDING}

The merger process of banks and financial institutions in Nepal has been going on continuously some year now. After The Nepal Rastra Bank (NRB) has introduced a policy to increase the capital of banks and financial institutions, it seems that banks and financial institutions have been merging and absorption, issuing right share, and distributing bonus share to raise capital according to the category of banks. This practice has seen some positive and some negative changes in Nepal's share market. As the size of total deposits and loan has increased and investment opportunities have been created, the financial position of weak institutions has also improved when they merged with strong institutions. For example Parbhu finance has become a strong bank of various development banks and financial institutions.

While Nepal Rastra Bank (NRB) was pushing for a big merger last year, some commercial banks are in the process of merging and some are in searching to process of right merging partner. Accordingly, the focus is on the post merger situation of Global IME, NMB and Prime Commercial. After the merger, the capital structure of all banks has increased. According to Global IME Bank has become the largest bank in Nepal. Similarly earning per share and net worth per share of all bank appear to have declined. The main causes of decline are the ratio of their profit and their share capital. P.E. ratio of all banks and the market value per share of NMB Bank seems to have increased, and the Global IME and Prime commercial bank has declined. However there are other factors besides M\&A that affected the stock market.

\section{CONCLUSIONS}

The big merger has directly and indirectly affected the share market of Nepal. Nepal Rastra bank has been practicing merger for the past few years as per the policy of reducing banks and financial institutions. Accordingly a large number of finance companies and development banks are merging with A class banks. As of today there are 27 commercial banks operating in Nepal. Nepal Rastra Bank aims to reduce it to around 15 only. At present Global IME bank has merged with Janata bank. Prime commercial Bank, NMB bank and Mega bank will be merged with various development bank and finance companies. As a conclusion the structure of banks likes Capital structure, Earning per share, P.E ratio. Market value per share and other various index seems to have changed after the merger.

The merger of bank and financial institutions has had a positive impact on some of the financial indices since the merger. According to the NRB's policy of increasing of capital of bank and financial institutions a year ago, the share market has not made encouraging progress due to the huge increase in the number of share distributed by bank and financial institution. In current put forward by NRB;s merger policy has seen many positive signs after the merger, such as employee benefits and security, investment opportunities, change in interest rates and the size of credit flows.

\section{REFERENCES}

Daniya, A. A., Onotu, S., and Abdulrahaman, Y. (2016). Impact of Merger and Acquisitions on the Financial Performance of Deposit Money Banks in Nigeria. Arabian Journal of Business and Management Review, 6(4): 1-5.

Das, S. (2014). Performance Mantra of the Regional Rural Banks: An Evaluation between the Pre-merger and Post-merger Era. Jindal Journal of Business Research, 3(1-2): 14-28.

Feroz, E. H., Kim, S., and Raab, R. (2005). Performance measurement in corporate governance: do mergers improve managerial performance in the post-merger period?. Review of Accounting and Finance, 4(3): 86-100.

Harrison, J. S., Hitt, M. A., Hoskisson, R. E., and Ireland, R. D. (1991). Synergies and post-acquisition performance: Differences versus similarities in resource allocations. Journal of Management, 17(1): 173-190.

Lees, S. (1992). Auditing mergers and acquisitions-Caveat emptor. Managerial Auditing Journal, 7(4): 6-11.

Patel, R., and Shah, D. (2016). Mergers and Acquisitions -The Game of Profit and Loss: A Study of Indian Banking Sector. Researchers World, 7(3):92-100.

Rani, N., Yadav, S. S., and Jain, P. K. (2015). Financial performance analysis of mergers and acquisitions: evidence from India. International Journal of Commerce and Management, 25(4): 402-423.

Shanmugam, B., and Nair, M. (2004). Mergers and acquisitions of banks in Malaysia. Managerial Finance, 30(4): 1-18. www.sharesansar.com

www.nepalstock.com 